\title{
Balkanologie
}

Balkanologie Revue d'études pluridisciplinaires

Vol. XI, $n^{\circ} 1-2$ | 2008

Volume XI Numéro 1-2

\section{Being Gypsy in Europe. The Case of Bulgarian Roma Workers in Spain}

\section{Magdalena Slavkova}

\section{(2) OpenEdition}

1 Journals

\section{Electronic version}

URL: https://journals.openedition.org/balkanologie/1102

DOI: 10.4000/balkanologie. 1102

ISSN: 1965-0582

\section{Publisher}

Association française d'études sur les Balkans (Afebalk)

\section{Electronic reference}

Magdalena Slavkova, "Being Gypsy in Europe. The Case of Bulgarian Roma Workers in Spain ", Balkanologie [Online], Vol. XI, n 1-2 | 2008, Online since 31 décembre 2008, connection on 28 juin 2022. URL: http://journals.openedition.org/balkanologie/1102 ; DOI: https://doi.org/10.4000/ balkanologie. 1102

This text was automatically generated on 17 December 2020 .

(c) Tous droits réservés 


\title{
Being Gypsy in Europe. The Case of Bulgarian Roma Workers in Spain
}

\author{
Magdalena Slavkova
}

1 The multidimensional character of identity enables speaking of various ones, revealing different aspects of community societal positions. The dynamic processes of the enlarging and integrating Europe arouse and continue to arise significant changes in the processes of experiencing of identity/identities and their expressions. The identity of the communities is laid on new conditions and it acquires new dimensions, so that we could speak of new forms of identity negotiation. The changes caused by the downfall of the socialist regime of governance in Bulgaria in the last 19 years and the ensuing social and economic crises led to the migration waves towards Western Europe and Mediterranean area. Spain became one of the preferred destinations for work abroad.

2 In the article I deal with the new significations of Gypsyness generated by the transnational labor mobility of Bulgarian Roma. I have adopted the ethnological approach. It is based on field work carried out in the cities of Murcia and Cartagena in Southeastern Spain and settlements in different parts of Bulgaria. The link among the communities dealt with in the text is the "journey" to Spain.

\section{Gypsies in Bulgaria}

The heterogeneous community of the Bulgarian Gypsies leads a varied way of life ${ }^{1}$. Part of them speak Romanes (Gypsy language), but to others the mother tongue is either Romanian, Turkish or Bulgarian. Some of the Gypsies are Christians (Orthodox or Protestants), yet others are Muslims.

4 The most important distinctive marker among the Gypsy groups is the selfconsciousness of belonging to the community. The combination of the criteria such as vocational specialization, lifestyle, religion, language etc. impacts the complex structure of Roma identity. In the recent past some of the Roma led a mobile way of life (Rudari, Košničari, Kardaraši, Burgudžii, Thracian Kalajdžii, Čelenderi, Kamčibojlii, 
Carenge roma, etc.), unlike those whose ancestors have long since settled (Erlii, Muzikanti, Xoraxane roma, Dasikane roma, Asparuhovi bâlgari ["Asparukh Bulgarians", they define themselves like this after the name of the old Bulgarian Khan Asparukh, whom they consider to be their "king"], Millet, Gypsies with a preferred Turkish identity, etc.). The last of nomadic groups settled after the 1950s, when the No. 258 decree of the Council of Ministers ordered compulsory sedentarization and settling at a given address of all nomads ${ }^{2}$. In the majority of the Gypsies the endonym of the group originated from the kind of livelihood they practiced or have practiced - for example Košničari (they weave baskets, chairs, flower stands, etc.), Kalajdžii (because they tinned utensils), Muzikanti (they play music), Čelenderi (they manufactured various hardware, etc. $)^{3}$.

5 The inclusion of the Gypsies in the common migration flows varies according to the group and thus the question should be asked whether the former nomads or settled Gypsies were more likely to practise labour in emigration. Overall, both representatives of the two communities - former nomads and settled Gypsies - leave. Altogether the successors of the Gypsies who had settled for centuries in the Bulgarian lands dominated the migrant scene. Representatives of almost any settled communities tried their luck abroad. Leaders from the former nomads in the illegal labor mobility are the representatives of Rudari group. Generally, representatives of communities who led a different way of life and had practiced and some of the partly still practice specific traditional crafts left for the Iberian Peninsula. An interesting moment in the period after the gradual settling down of the former nomads from the 1950s onwards was the inclusion of the Gypsies in the new socialist cooperatives, the so-called TKZS (Labour Co-operative Farms) and the DZS (State Farms).

6 After 1989 the Gypsies were involved in various labour spheres and implemented varied economic strategies, some of them had not been practiced before. Some of these are "illegal business", for example the bearings scam by the Burgudžii. Gypsy NGOs also began to appear, as a new way of solving the problems of the Roma and realising the activity for the "Roma community" through the financing of various projects by different sponsors ${ }^{4}$. During that period, pick-pocketing by the Kardaraši increased. The groups of Gypsies from Bulgaria turned towards cross-border labour mobility as a new economic strategy and form of adaptation in search of a way out of the difficult economic and social situation.

7 Moreover, the out-migration does not constitute a new phenomenon. During the socialist years transnational migration was also known among Bulgarian citizens as included work in destinations inside or outside Europe (socialist states, USSR, Libya, Israel). Roma men (or families) are active participants in the out-migration flows as well. They have worked mainly as constructors or musicians. The current migratory movements originating in Bulgaria resemble a traditional pattern in the area, the socalled gurbet, through which workers migrated abroad for short periods of time (usually for one working season, depending on the type of the labor activity) in order to provide some extra income to their households, where the families are left behind ${ }^{5}$. Like the surrounding population initially the Roma stuck to the common Balkan migration pattern of the gurbet. Until 1878 workers on gurbet migrated to other regions in Central Europe under the control of the Ottoman Empire, but after that date and until the thirties of the $20^{\text {th }}$ century one of the preferred destinations for Bulgarians had been the US ${ }^{6}$. Nowadays it could be often heard that the family or some 
of the members is/are on gurbet, the transnational workers are called gurbetchii as well.

\section{The Experience of Migration towards Spain}

Spain is a Mediterranean country and is situated in Southwestern Europe, thus it is quite far away from the motherland of Bulgarian Roma migrants. Nevertheless, Spain is one of the most preferred destinations and an important area of European mobility of Bulgarian citizens in the Mediterranean. Spain is one of the states, once known for outward migration (in the 1970s), transformed later to a country receiver of immigrants ${ }^{7}$.

Contemporary migration movement towards Spain have developed since 1990, as it could be determined three main flows - in the end of 1990s; since 2001 when Bulgaria was removed from the "black Schengen list", which scrapped the visa regime with Spain ; since 2007 when the state has joined the European Union, and Bulgarian citizens are able to travel freely to Spain only with their IDs. The statistic shows that nowadays the most attractive destination for both Bulgarians and Rumanians still remains Spain.

During the years after 1989 the Kingdom became an attractive destination for work of all Bulgarian nationals ${ }^{8}$. After the mid-1990s the process sped up and could be named a "migration wave" in that direction, thus the Bulgarian migration to Western Europe took on a larger dimension prompted by the economic crisis. The year 2001 constitutes an important turning point in the migratory movements originating in Bulgaria. The Bulgarian residents are able to stay without visa for a maximum duration of 90 days every six months from the day of the first entry in a Schengen state. The possibility to travel regularly between Bulgaria and Spain has set off a new migratory process, a pendulum migration'. In January 2007 Bulgaria joined the European Union, and now Bulgarian residents are able to travel freely within the Union only with their IDs. Border control has been suspended in terms of marking the date of exit and entry, and "black" seals are long gone. However, the Spanish governments apprehended that Bulgaria's membership would translate into large numbers of immigrants and have imposed a moratorium on the entrance of Bulgarian and Rumanian migrant workers until 2009. This means that those who wish to work still need a special permission given by the government. In recent years migration towards Spain is still going on, but at the expense of neighboring Portugal in some cases because of the saturation of the Spanish labour market.

11 It is hard to say exactly how many Gypsies have left Bulgaria to work in Spain. Researchers say that migration from Bulgaria has an ethnic profile and that in some communities Gypsy emigration prevails ${ }^{10}$. According to data of the Bulgarian National Statistical Institute (NSI) in $20019 \%$ of the emigrants believed Spain was a country where they could work and solve their material problems. In 1992-1993 nearly 60 000-65 000 people left Bulgaria but it is not clear how many of them were Gypsies ${ }^{11}$. The deterioration of the social and economic situation after the mid-1990s invigorated the dynamics of the migration process. After April 2001 we could count some 600 000-800 000 people who left Bulgaria, again without a notion how many of them were Gypsies ${ }^{12}$. According to data for 2007 of the Spanish national statistical institute (INE), the number of Bulgarian nationals residing in the country is 122057 and the greatest number of them lived in the administrative regions of Valencia and Madrid, 
27542 and 26 306, respectively ${ }^{13}$. In all likelihood the Bulgarian migrants, including the Gypsies, in Spain outnumber the above-mentioned figures.

The main and defining reason for emigration in Spain is the economic drive. The transition from a government-run to a market economy in the 1990s in Bulgaria has been related to the high inflation and unemployment rates that affected the entire population of the country. Many Gypsies remained without jobs when the industrial giants of the past closed production and the agricultural cooperatives went bankrupt. The common crisis affected severely all ethnic communities but the Gypsies in particular $^{14}$.

The various Gypsy groups could have a different motivation to go to work in the given country. The Rudari with their subdivisions of Lingurari ("spoonmakers", also called Kopanari, "troughmakers") and Ursari ("beartrainers") are the most active among the Gypsies who used to lead a mobile way of life. They are one of the first group of Gypsies who started work abroad: at first in Greece and Cyprus and then in Spain, Italy and Portugal ${ }^{15}$. An important reason for them to prefer Spain is the proximity of their mother tongue, Romanian, to Spanish. The representatives of the Carenge roma (from "cara" - a Gypsy camp) from the regions of Pazardzhik and Peshtera, the Čelenderi from Yambol region, and the Kamčibojlii from Burgas region (all of the towns are in Southern and Southeastern Bulgaria) are also active in the practice of migrant labour. Spain became a popular destination for labour with them just like with the rest of the Bulgarian nationals for a number of reasons, including the existence of already established migration networks. Unlike those groups, the Thracian Kalajdžii, the Burgudžii etc. take almost no part in the migration processes or have registered only isolated cases of travels abroad. The Kardaraši joined the processes of cross-border mobility, but their excursions took a specific shape (the practice of pick-pocketing). Bulgarian Gypsy migrants in Western Europe in their majority migrate as composite (though in some extent separate) part of the overall migratory waves of citizens from the country of their origin. They as a whole repeat in big extent the same basic strategies of labour mobility. In this meaning, there is no difference in migratory patterns between the settled for centuries Gypsies and the ones, who are former nomads, relatively soon settled (during the 50es and $60 \mathrm{es}$ of the $20^{\text {th }}$ century). The main reason is that the most of the former nomads have preserved many of their group characteristics and inter-group social organization. Indeed, they adopt the changes in the society they live in their own way in comparison with settled Gypsies, where the changes reflect them stronger.

Spain is one of the most remote destinations in the EU from the point of view of distance from Bulgaria and the ride by coach takes nearly two-three days. The Gypsies, like the rest of the Bulgarians, use various transportation means to get there. Those who leave try to respect the requirements of the law for travels abroad in order to guarantee the success of their journey, despite the fact that often they use forged papers to prove the purpose of their travel. One of the most common ways to get to Spain is through the use of the so-called "traffickers" (kanaldzhii), who drive their passengers across the border in vans and rely on a network of "traffickers". An informant I met in Murcia in May 2006 had arrived in Spain via a network of traffickers, and had paid $€ 200$ to get to Spain and only $€ 70-80$ to get back. A popular way to travel until April 2001 was the tourist visa to Spain that guaranteed legal passage at the border checkpoints. Bulgarian migrant workers went to Spain by bus since a bus ticket 
costs not too much and making the trip economically possible for most people. The freedom of movement along the EU inaugurated in 2001 also meant a diversification of the means of transportation used by immigrants. Indeed, to travel by airplane is becoming a popular means of transportation from Bulgaria to Spain, although the bus still is very popular. Flying in many ways avoids unnecessary border control and has fewer risks. The long-lived in Spain Rudari usually travel by plain because they have a financial opportunity to do it and self-confidence of workers earning well. Altogether, the Gypsies like all immigrants try to spend less on travel fares, so they always find the mot feasible way to make the journey. A car ride supposes greater convenience, those who travel are "inconspicuous", and could state various purposes of their journey in front of the border officials. A family of Kamčibojlii left for Spain in their own car in 2004. They were going to Lorca (Southeastern Spain, region of Murcia) to a friend of the father of the family, who had promised to help them find work and a place to stay. Before they reached Italy they told the border officials they were going to visit a grandfather who lived in Italy and whom they had not seen in a while.

\section{Roma Workers in Spain}

The Mediterranean area in Spain became very popular destination among the migrants, including Gypsies. The transnational workers usually direct their migratory projects to the two types of settlements - big cities which are situated near the capital city of Madrid or they arrive at the nearby towns of the capital of the Spanish provinces (Burgos, Valencia, Murcia, Bilbao, etc.). The second mode is oriented to the small towns and villages, which are situated, however, in developed tourist regions or in fruitful agricultural regions.

16 The most desired destinations of the Gypsies for practising migration labour are the South of Spain (Comunidad de Andalucía, Región de Murcia), the East and part of the North of the country (Comunidad Valenciana, Cataluña, Aragón, Castilla y León). There are a great number of Gypsy migrants in País Vasco (Northern Spain) as well. The central areas (Comunidad de Madrid and Castilla-La Mancha) are some of the most attractive destinations. Migrants prefer those regions because they can easily find relatively well-paid work there. Certain tourist sites are located in those regions, which creates more jobs and offers a variety of activities to do. In the northern regions (Galicia, Asturias, Cantabria etc.) there are only a few Bulgarian immigrants due to the fact that they are underdeveloped in economic terms compared to the rest of the country.

17 Gypsy migration to Spain is in most cases in the short term, but there are examples of a transition from cross-border labour mobility to lasting emigration. Seasonal mobility processes have been registered among migrants, in whose families only one or two members work abroad during the farming season, and then return to Bulgaria and then go back to Spain again. There is another type of longer lasting labour migration in Spain, that can also be termed "temporary", because the family wishes to return to Bulgaria forever after some time, but meanwhile they will have to "make some money". In both cases they work abroad but wish to settle in their land of origin. The transition from cross-border labour mobility to lasting emigration happens when the first children in immigration are born, or when their children born in Bulgaria join them in 
immigration and have to start school or socialize in the new surroundings. Thus, a process of legalization in the host county begins.

Spain is an example of availability of Gypsy migrant clusters, mainly with Rudari residents. The predominant number of migrating Gypsies headed for destinations where they already had relatives or close people who could help them adapt, find a job and a place to stay. The latter condition turned out to be a powerful factor as it created in migrants the feeling of security, whenever they stayed with their families and kin. Similar to other migrants they adapted more easily by means of grouping together or the so-called "chain migration" ${ }^{16}$. The first people who left for Spain were followed by other family members, their relatives, and finally, the neighbours and other acquaintances from the neighbourhood. In some Gypsy neighbourhoods in Bulgaria almost each family has a relation or a more distant family member working in Spain. The multiple stage migrations (migrations of relatives that take place in several stages) are characteristic of both the Bulgarian population and the Gypsies. Settling by means of grouping together provides quicker adaptation to the new living conditions and helps preserve the identity of the migrants. In some regions the migration process has acquired such dimensions that the Gypsies from the same neighbourhood go to the same city or village abroad, whereas people from another neighbourhood in the same place of origin in Bulgaria leave for a totally different part of Spain or even another country. For example the Gypsies from Peshtera (Gypsies with a preferred Turkish identity, Carenge roma, Dasikane roma) have had years of experience in emigration to Western Europe ${ }^{17}$. The former inhabit the Ediveren neighbourhood, while the rest live in the Lukovitsa neighbourhood. The Ediveren Gypsies emigrate mostly to France (Bordeaux) and Germany (Berlin, Stuttgart, Dusseldorf), whereas Dasikane roma and Carenge roma from Lukovitsa go to work in Southern Spain (Murcia; El Ejido, Matagorda, province of Almeria) and Northern and Central Portugal (Porto, Guarda). In certain regions of Bulgaria the Gypsies always choose the same countries to go to and "try their luck". Thus, the Rudari from Byala Cherkva (Veliko Turnovo region, northern Bulgaria) emigrate to Spain and Italy, and those from Burgas region prefer to go to Greece, mainly. The Turkish Gypsies from Balchik and Kavarna (northeastern Bulgaria) prefer to work in Poland, whereas the representatives of the same group from Sandanski (Southwestern Bulgaria) go to Cyprus, Greece and Spain. During my fieldwork in Bulgaria I came upon the Rudari neighbourhoods (Pleven, Vratsa region, etc.) of which the adjective "barren" would not be an exaggeration. The shops in Letnitsa neighbourhood (Pleven, northern Bulgaria) had padlocks on. Most of the houses were empty, elderly women set on the benches outside their homes and little children were playing around. The able-bodied population had gone to Spain.

If the respondents had remembered and know the exact location of their family and acquaintances from the neighbourhood abroad, that would attest to a well-developed migration process. For example, Dasikane roma from Lukovitsa neighbourhood in Peshtera have families in El Ejido and Matagorda, some of the Gypsies from Sliven (Muzikanti, Dasikane roma) have closer or more distant relatives in Murcia. Informants from the group of Muzikanti from Kotel periodically perform in Barcelona (northeastern Spain), while the Muzikanti from Zlataritsa live and work in Bilbao. The Asparukh Bulgarians from Kotel emigrate to Zaragoza (northern Spain), Barcelona and Madrid. I talked to Kamčibojlii from Aitos (Burgas region), who until recently had worked in Lorca and others in Madrid. The Košničari from Lukovit (Pleven region) and the Gypsies with a preferred Turkish identity from Pleven region have relatives in 
Madrid. I met families of Rudari from Byala Cherkva, whose relatives lived and worked in Valladolid, Iscar (northern Spain, province of Valladolid), Valencia (eastern Spain) and Rudari from Shabla, whose acquaintances were in Madrid and Cuenca (central Spain, district of Castilla-La Mancha). Gypsy musicians from Pernik (Sofia region) have relatives in Cartagena and Madrid.

Spain became popular with the Bulgarians as a destination for migration because in their opinion one could find a job and earn more or less well. The authorities in Spain have de facto accepted and aided the expansion of labour migration through regular campaigns to legalize migrants ${ }^{18}$. In 2005 Spain launched a campaign for legalizing the status of those not allowed to stay. The government granted a legal stay status to some 500000 illicit immigrants who had a labour contract, had spent at least six months in the country (had a registered address) and had not committed criminal offence. More than 20000 Bulgarian nationals who did not have a permit to stay applied for legalization of their stay ${ }^{19}$.

21 Spain started to become a net receiver of immigrants, so that nowadays there are many Latin Americans, Arabs and Africans living illegally/legally in the country. The Spaniards have become more or less used to being surrounded by people of different ethnic origins and a different color of the skin, so none of them was shocked by the fact that the labour from Bulgaria were Gypsies, nor has it been made into a problem. On the other hand, the Spanish residents find it hard to distinguish between Bulgarians and Gypsies and assume that they are Bulgarians. That is particularly so when the migrants do the same kind of labour, lead a similar way of life and in some cases inhabit the same immigrants' quarters.

A characteristic feature of the Gypsy emigration towards Western Europe, Spain in the case of this paper, is its gender and age profile. The Gypsies from Bulgaria do not look much different from the surrounding population in their common migration strategies. Within the framework of the common migration flow they preserve a certain isolation as community (mostly on group or regional-residence) level, which remains once they have settled in the foreign country. At first, one family member leaves the country. In this case women are equal participants, and in many cases it is women who leave abroad, while the men stay behind. The feminization of transnational labor mobility is a typical for Rudari; it could be observed in some cases among the Turkish and Bulgarian Gypsies, but rarely among the Millet (i.e. "people", they are Muslims), the Gypsies with a preferred Turkish identity, etc. Sometimes, the first to leave are single young men. The reason is that they do not have a family or children to look after, and this enables them to adapt more quickly. Another important prerequisite for their journey is the high unemployment rate, especially in the countryside, among the young able-bodied population and the lack of prospects for fulfillment in Bulgaria. According to an informant from Peshtera, one of the first from the Lukovitsa neighborhood to leave form Spain was his grandson. He left for Spain 11 years ago. He stayed there a few months after failing to find a job, and moved on to France, where a Serbian Evangelist helped him to find a job. The Serb invited him to his home, gave him food and helped him to learn French. Currently the grandson is still in Bordeaux, and owns his own construction company.

The next stage is that all the able-bodied family members leave. In the event of only one family member leaving the country, travel fares and expenditure for settling in the new place are lower. This turns out a major advantage to many families. Gradually, 
cross-border mobility expands and the able-bodied young people leave in emigration. Only the elderly generations remain to look after the little children. This is where the principal difference with the emigration of Romanian Gypsies towards Spain lies. In most cases entire families leave creating the impression that they leave for $\operatorname{good}^{20}$. Another form of emigration with the Bulgarian Gypsies is several family members traveling together (a family couple, two brothers, a mother and her son, an uncle and nephew etc.). Migrants hope they will adjust more quickly to the new surroundings by having a close person by their side. Respondents have admitted to the common belief that it is always better that spouses should stay together in order to preserve their family. For instance, among the Gypsy musicians men travel and work abroad alone as well as with their spouses because they have joint performances at the street or in restaurants.

Upon their arrival on the Iberian peninsula the Bulgarian Gypsies find themselves in a foreign country, with a different living standard and culture. Adaptation to life in the Kingdom to each of the families is of various duration and difficulty. However, the representatives of the separate communities happen to be extremely flexible in their ability to find work and to "get used to the conditions". Some of the Gypsies are forced to live (albeit initially) in very difficult conditions that might seem unacceptable to other migrants. In any case the family, or group principle of settling, followed by the neighbourhood/city/village and finally the country principle (for example, Gypsies from Bulgaria) is observed in decreasing order of importance. The collective way of life preserves the traditional norms, and migrants feel in their own element even away from their land of origin, and it also helps save money for room and board. In the first years of emigration people often left for Spain "to try their luck" without a clear idea where they were going and what they were going to do. A lady informant from Sliven arrived in Spain many years ago, but had no relatives to stay with and "slept in the fields" until she picked the language and found a job. When settling the emigrants prefer places where they have relatives and acquaintances who have already established themselves. Thus, the Rudari from Byala Cherkva leave for Iscar, whereas the Rudari from Vratsa region preferred to go to Burgos, Segovia, Zaragoza (Northern Spain, Castilla y León) etc. Once they arrived in Spain the Gypsies from Bulgaria settled in immigration quarters, where they could find cheaper lodgings. Thus, a musician from Pernik has rented rooms in the old part of Cartagena, where mostly Arabs live. A family of Kamčibojlii from Aitos settled in the Moroccan quarter in Lorca, where life is cheaper, and the other inhabitants are Muslims lime them. In Patiño (Murcia region) I met Gypsy immigrants from Bulgaria and Romania. They lived together is an abandoned semi-dilapidated building. The workers from Bulgaria were originally from Kyustendil (Western Bulgaria) and Pazardzhik region. Most of them were men, but there were a few family couples. All of them had rented a single room. Next to them lived Romanian Gypsies. What is interesting in this case is that some of the Bulgarian and Romanian Gypsies were Evangelists and in their free time they held religious services on a meadow in the open air ${ }^{21}$. The Gypsies from two neighbouring countries feel they have more in common because of their common faith in Jesus Christ, compared to their common ethnic origins. i.e. the fact that they are Gypsies. The Gypsies turn to the immigrant hostels run by various charities only as a last resort. In one such hostel ("Jesús Abandonado") in Murcia in May 2006 there was not a single Bulgarian or Romanian national. Most of them were from Mali, Mauritania, Senegal, Ghana, etc. Very seldom migrants from Bulgaria can afford to stay at a hotel while they 
work abroad. However, there are exceptions. For example a lady informant from Kotel and her husband work for a month or two abroad (including in Spain) as musicians. For the time of their stay they always hire a hotel and seldom use private lodgings.

\section{Labor Activities and Performance of Identit(ies)} and professional qualifications are not winning in order to include at the Spanish labor market. On the other hand, even they have higher qualification it is quite difficult to realize because they remain immigrants. More chance in that way have their children who educate in the local schools, socialize in the new conditions and could be integrated successfully in the society. Enjoyment of the required permits for work and stay is an important factor to be practiced one or another job in Spain. The foreigners who wish to stay and work legally in Spain need to produce Autorización de residencia y trabajo en España ("Stay and work permit"). The official Spanish name of the papers has coined the term residencia, which has become a familiar word with the immigrants in Spain and their families in Bulgaria. A lot of Gypsies (as well as other Bulgarian nationals) live and work in Spain without the required permits and are in fact illegal or semi-illegal (i.e. they have a permit to stay, but not to work). The Gypsies I met in Murcia in May 2006 had already been living there for several months without the right papers. Other of the Gypsy informants have spent years in Spain at the time I met them and had even taken their families with them and had residencia.

The labor activity of the Bulgarian Gypsies in Spain is gender specific. There is a professional specialization with the communities as tradition. The Gypsies repeat overall the patterns of the surrounding population in finding a job abroad and the community distinction is at a lower level within the common framework of the crossborder mobility of the Bulgarian residents. They fill in shortages of cheap labour in various spheres and do different kinds of unqualified labour. Often Gypsies from 
various groups work in the same field. Some communities turn to specific ("marginal" in society perception) activities when abroad (for example begging), that are either a modified version of a previous occupation, or a new kind of economic strategy. In this way they resemble some of the groups of Romanian Gypsies, who also opt for marginal activities in Spain $^{23}$.

There is a local Gypsy population in Spain called Gitanos (or Calé/Calos). Their living standards are higher than those of the Balkan Gypsies, and they occupy their specific economic niches and do not have professional contacts with the Gypsy immigrants. The only migrants with which the Gitanos could have had certain relations or origins of such relations are the Evangelists. The Gypsy Evangelists hope to find work by means of the Evangelist network, as well ${ }^{24}$. Keeping in mind the religious profile of the migrants (Muslim, Orthodox and Protestants), we could say that the Evangelists are the one who help each other out to the greatest extent. The other practise their religion both in Spain and in Bulgaria is a rather passive way and religion is not a key factor in emigration. Solidarity in the labour sphere among the Bulgarian immigrants is manifested at various levels with the family principle being the leading one. The communities be it former nomads or long ago settled have various ideas of how money should be earned and families fed, and therefore have different visions on "morality" in business dealings. If some of the groups turn to begging, others consider it a "very shameful occupation".

Women and men do different kinds of work. The Gypsies manage to find work in a limited number of areas - agriculture, social and public service, construction and music entertainment ${ }^{25}$. Jobs in the agriculture are more often than not seasonal ones and engage in all sorts of vegetable and fruit picking - oranges, lemons, olives, grapes, peaches, tomatoes, artichokes, lettuce, cucumbers, beans, potatoes, etc. People work wages or a certain daily output they have to submit as minimum requirement, either in the fields or in greenhouses. Both men and women opt for this kind of work. For example a family of from Aitos has been living in Lorca for several years. The whole family began work (the mother, the father and the two children) as seasonal hands in the agriculture sector. An Ecuadorian hired them. The children went to a Spanish school, and in the weekend and during the school holidays they help their parents put in the field. Rearing domestic animals (goats, etc.) is another option for employment in Spain. This sector hires more often men, but also women. After some time the father of the same Kamčibojlii family contacted some Moroccan employers from their quarter and found a job as a driver, who drove workers to the field, while his wife started rearing goats. Many of the Rudari migrants are busy in farming as seasonal workers. Women migrants often work in the social and public sphere services. They are either housemaids or look after elderly and sick people. Sometimes the women work as cleaning ladies in various offices or do the washing up in restaurants. Men in the same sphere work as gardeners (maintenance of private parks and gardens) in the homes of well-to-do Spaniards. They can also find work in the transportation business. A key area of employment for the qualified male labour is construction and other related activities. They usually start as unqualified. Men from various Gypsy groups do that. The nephew of a Rudari informant from Turnovo region has been residing in Spain for many years. He works as a wood carver there. In Bulgaria he graduated the Vassil Levski Higher Military University in Veliko Turnovo, but has never worked in his major. 
The Gypsy musicians work abroad too. They are either street musicians or get hired to play in restaurants. The people from musicians' families earn their living in Spain by doing only this ${ }^{26}$. Some of my informants were descendants of family military band musicians, who originated from Kotel (Sliven region). The Muzikanti when abroad play various versions of Balkan (including Gypsy songs), popular, and traditional European music ${ }^{27}$. This occupation is regarded as a prestigious one, because it earns "good" money. Playing in the street is also prestigious because of the good earnings and the positive attitude of the Spanish people unlike the attitude in Bulgaria, where street musicians are perceived as beggars. An informant and his family have been residing in Spain for a few years. They live in the country legally and own a flat in the central part of Murcia (old lodgings from the times of general Francisco Franco [1939-1975] in an immigrants' quarter). He teaches music lessons to children in a culture club, and performs at concerts. In his free time he works as a street musician. The informant said he would not give up playing the accordion in front of Murcia's Cathedral because he made good money and there was his "office", i.e. the venue where he struck his professional engagements. Street musicians shared the key areas suitable for making music in the central city areas. In this way they do not stand in one another's way and earn money each for themselves. During my stay in Murcia my informant from Sliven introduced me to a colleague of his, an accordion player from Romania (from the group of the Lautari). The two musicians played in the city centre, in the same area, but had placed one another at such a distance so as not to get in the way of the other and thus, lose customers. In Kotel I met some informants who had been working as gurbet makers in a Greek Tavern in Barcelona. Later they decided to work as street musicians in the French city of Perpignan. The husband and the wife have been touring the world as musicians since the 1980s. They have worked in various countries - Bulgaria (in the resorts), Germany, Poland, Spain, and France. They spent a month, or two at the most, abroad, after which they returned to Bulgaria and then left again. The lady informant performed Bulgarian folk songs, Gypsy songs, etc. while the husband accompanied her singing.

Some of the migrants manage to find a more lucrative and more prestigious job with time. This is usually accessible to immigrants, who have been residing in Spain for many years, and have learned the language well, and also the local ways. Some of them find fulfillment as chefs, or assistant chefs, shop assistants, factory workers, etc. I met a lady informant in Spain, a Gypsy woman from Sliven, who had settled in Murcia with her son for several years. She worked as a housemaid. She had found an extra job as a mediator to the ASPROSOCU NGO. Her work consisted in contacting Bulgarian Gypsies, helping with conducting interviews and interpreting from and into Spanish.

There are isolated cases when the Gypsies get involved in the criminal world, for example, soliciting in the West (including in Spain). In my opinion however we cannot establish a trend, and a large-scale participation of Gypsies in the shady business. Begging is a typically Gypsy adaptation strategy and representatives of groups, who have not practised it in their home land (at least the latest generations), turn to this trade. The relatives from the neighbourhood refuse to comment it, and keep it a secret, and talk of an occupation beyond any doubt in front of neighbours and acquaintances. Beggars have problems with the police, if they are caught red-handed, but the benevolent attitude of the Spanish people towards those "seeking mercy" and the money they make, allow begging to exist as a possible occupation. I met a few Bulgarian 
immigrants who worked as beggars in front of the Catholic churches in Murcia, despite the fact that they themselves were Muslims or Evangelists. They usually "work" in couples, man and woman. All informants are unanimous that begging was only a temporary "job" while they found something "better", and "more suitable". The migrants I met in Murcia said they would continue begging until the season for the picking of the peaches and the artichokes began. They said begging was not considered shameful in Spain and that the local people always left a coin in the plastic goblet with a smile. In Murcia there has been a non-written distribution of the territory for work among the Bulgarian and Romanian Gypsies, as well as among the Bulgarian Gypises from various places and regions in Bulgaria. In most cases I saw Romanian Gypsies beg in front of underpasses (the women) or sell handkerchiefs (in pairs) on the road lanes to passing drivers ("hidden begging"). Among the group of the Kaldaraši cross-border mobility in a great number of cases takes a rather weird shape - taking girls or young married women, accompanied by the mother-in law or male relatives to pick pockets abroad. In Spain they go to "work" in the huge cities, Madrid, Barcelona, and Valencia.

To employers immigrant labour is cheaper than that of the Spanish people. The majority of the Bulgarian migrants are aware that labour without "residencia" costs less. A lady informant from the region of Vratsa told me about her experience in Spain. She and her sister-in-law were engaged as hired workers in agriculture and they worked on the field all the day. The owner did not pay them money, as he promised initially, but he gave them a bag with potatoes. The women could not look for their rights because they had not legal documents, neither the women spoke Spanish to take a conversion with him.

To a great many of workers, however, the money they earn is enough so that their families could lead a decent life in Spain and to help their relatives in Bulgaria. According to field work data, the musicians earned the most. For example, a night of performing at a Greek tavern in Barcelona earns a couple of musicians $€ 500$. Street musicians also make good money. Those who work wages (construction workers, farm hands, cattle breeders) earn $€$ 25-50 a day depending on the type of work and the region they reside in. Others, who work on monthly salaries (gardeners, housemaids, social workers, etc.) receive sums that are close to the country's minimum working salary. Those who do specialized labour get payment nearing the country's average salary. The Gypsy beggars in Murcia for example collect enough money to subsist on, but are unlikely to earn more, if provided they found another job, they gave up begging. It is difficult to tell how exactly how much pickpockets make on average, or per day or per month. The latter trade however is not without its risks, one of the being caught by the police.

The role of labour migrants in the overall economic life of the countries of Western Europe (and Spain) is an important one. Far greater is this significance to the countries in transition in Eastern Europe, and in particular Bulgaria (and Romania), where a considerable share of the money turnover is maintained with the help of the means imported from abroad and that the migrants send their relatives at home. According to data of the State Agency for the Bulgarians residing abroad, the Bulgarian nationals abroad had transferred through various bank accounts the sum of $€ 614$ million between January and October 2005. The emigrants in Spain assist their relatives in Bulgaria by regularly cabling various amounts of money in foreign currencies ${ }^{28}$. Entire families live on this "migrants' money", which helps maintain a certain living standard, 
often higher than that of the neighbours and acquaintances. The money is used for everyday needs, but also as investment in the construction of big houses. The elderly parents who have remained in Bulgaria supervise the construction works. The Gypsies in Spain send the money to their relatives via bank transfers (including via Western Union), or they give cash to someone traveling to Bulgaria. The most important purpose of the emigrants who leave Bulgaria is to "make money" and improve their living standards. Their everyday lives in Spain are organized around this objective. The principal strategy of their stay abroad is to save money, and to spend as little as possible on individual needs (room and board), so that they can have what to live on when they return to Bulgaria. The pending issues of the immigrants are related to finding employment and a place to stay, the care after their own survival and proving financial assistance to their families in Bulgaria.

One of the most difficult obstacles to life in Spain happens to be the command of the local language. Language problems are part of the everyday life of the Gypsies. Very often when they leave for Spain, they do not speak a word of Spanish (castellano). In most cases the migrants manage to learn the basics of the local language, so as to be able to handle the first-hand needs of the migrants. The lack of command of Spanish or any other western language limits communication to the confines of the familial community, and the acquaintances from the region and from Bulgaria, or Bulgarians. Employment abroad and life among a foreign-language speaking population is of particular significance to those who have come from Bulgaria regardless of their ethnic or religious identity. The feeling of belonging to the Bulgarian state (as Bulgarian Gypsies) is enhanced by during their stay in Spain. The common land of origin and the equal attitude towards the emigrants from Bulgaria as foreigners play a uniting role. Thus, the Bulgarian Gypsies are able to feel closer to the Bulgarians, unlike the Romanian Gypsies or the local Gitanos, with whose groups they almost never meet or get in contact. This applies also to the case of Rudari, who while are living in Bulgaria demonstrate usually identity of Rumanians (old Rumanians) and Wallachians, but during their stay in Spain they always present themselves as Bulgarians in front of Spaniards, not in meaning that they change their previous identity, but by reason of that through comparison with the Romanians from Romania they realize that are totally different from them. The Rudari avoid to speak in Romanian in front of the Spaniards in order do not think about them as Romanians or worse to identity them as Gypsies and thus to dismiss them. According to the interlocutors' talks the Romanians from Romania are worse workers and are thieves, so nobody wants to identify with them.

The duration of the stay in Spain influences the degree in which the newcomers master the castellano. The Gypsies who have lived there longer, have a better command of the language, which enables them to communicate with Spaniards, and use the services of various institutions. The children of migrants who have been residing in the country for many years and are able to attend Spanish schools learn the language very fast and in some cases better than their parents. Through communication with local peers the children get to know actively the customs and the culture of the environment in which they have found themselves. In many cases they develop a new identity, complex and bilateral. When I met a 16-year-old girl from Aitos she spoke hardly any Bulgarian at all, and was unable to read and write in Bulgarian. She has never been to a Bulgarian 
school and she communicates with her parents in Turkish. The only school she has been to is the Spanish school in Lorca.

Bulgarian Gypsies of various religions leave for Spain - Orthodox Christians, Muslims, and Protestants. The only ones who actively demonstrate and practise their religion are the newly converted Christians. The Orthodox Christians and the Muslims remain such by tradition without adhering strictly to the observance of religious prescriptions. Some of the reasons stated include the lack of time and conditions to practise their religion and the hard work. In Bulgaria things are almost the same. Unlike the Orthodox and the Muslims the Evangelists organize prayer meetings on every occasion, no matter when and where. In September 2004 I met Košničari from Lukovit. The informant's family had returned from an unsuccessful journey to Spain a few days before. Her son is in Madrid and some of his relatives tried to reach the country pretending they were paying him a visit and hoped that they would be able to find work there. But they were sent back at the Italian border. The day I met her the woman said she still felt the shock of what she had been through and would not go to church that day. When she felt better, she said, she would go to the church to thank her brothers and sisters in Christ that they had prayed for their successful journey to Spain. Emigration abroad is one of the key topics discussed during the praying gatherings of the Evangelists. The example is a clear indication of the fact that the journey to Spain has been "ritualized". Some of the Rudari are also converts and attend Evangelist churches. During the active farming season the people from the neighbourhoods leave to work in Spain. During that time no Evangelist gatherings take place because the spiritual leaders are abroad. Most of my informants in Patiño (Murcia) are Evangelists. Some of the men claim that they are preachers, ordained back in Bulgaria, including a Kelderar from the Romanian Gypsies. Religious services are held on the lawn in front of the common immigrants' home. On the day I visited them, they were expecting a visit from Gypsy preachers from Lom (northwestern Bulgaria), who had arrived in an attempt to conduct a large-scale baptization of Evangelists among immigrants. The Gypsy beggars in front of the Catholic churches in Murcia are also Protestants and when I met them one of the men showed me a business card of a local Evangelist of the Gitanos, whom they were trying to contact and ask to help them find work. Belonging to God's chosen, i.e. the Evangelist community, turned crucial in emigration. Practising the Evangelist religion is the only reason for which three various groups of Gypsies (the local Gypsies and those from Bulgaria and Romania) feel they belong to a community, that of the "newly converts" and those "who have believed in Jesus Christ". The Evangelists demonstrate initial steps of maintaining contacts among the three Gypsy groups, the Romanian, Bulgarian and Spanish Gypsies, which is almost non-existent among non-Evangelists. If Evangelists hope to find work through Evangelist networks, the other Gypsies do not care and would never get in contact with the Gitanos, whereas the Romanian Gypsies openly consider them dangerous and job rivals.

On the other hand, the Bulgarian Gypsy migrants share the same fate as the Romanian immigrants. Except for residing away from their homes, they often do the same jobs to earn their living, inhabit the same immigrants' quarter, and have the same problems. The two communities however keep the borderline. They differ not only in their community, but also in their national belonging (Gypsies from Bulgaria and Gypsies from Romania). The land of origin is important because it becomes an important marker of distinction from the rest. The Romanian Gypsies are more "visible" to 
Spanish society because of their huge numbers and the fact that some of their women (in some groups at least) preserve part of their traditional costumes, the long skirts, the long hair and the mandatory headscarves, or the wearing of various "Gypsy" jewellery. The presence of the Bulgarian Gypsies remains almost unobtrusive because at first sight they do not differ considerably from the Spanish. The Gypsies from Bulgaria maintain their group identity and tend to distinguish themselves from the rest of the communities on that basis.

The migrants in Spain maintain their contacts with their relatives in Bulgaria over the phone in most cases. The phone is used to discuss family matters, material issues, and exchange greetings on holidays. With the help of an informant from Lom (Northwestern Bulgaria), who owns a snack-bar in one of the four Gypsy neighbourhoods and telephone booths with preferential costs of abroad calls we managed to determine in which countries there worked people from the quarter. In his words, the most common phone calls the Gypsies form the neighbourhood were to Germany, Italy and only a few families called relatives in Spain.

The migrants who have resided in Spain for a long time have felt the influence of the local customs on their way of life and identity. With time the entire family settles in Spain. The children are able to socialize in the new environment. Gradually the ties with Bulgaria and the more distant relatives are severed, their stay is legalized and they settle permanently. The family members begin more active communication with the locals and also benefit from the advantages of the "Spanish way of life". They start feeling more "Spanish" than the temporary migrants. Rudari, for instance, in all cases try to celebrate traditional feasts, no matter in modified variant. One of the most important feast and along with this group characteristic for Rudari is the celebration of gurban (the kurban is a wide-spread Balkan tradition with ritual sacrificial offering of an animal on a given feast in the name of saints or for good health, etc.), which plays crucial role in traditional self-identification. Living abroad they continue to celebrate the gurban, but do not practice the ritual blood sacrifice and just buy a lamp or part of lamp from the local shop. The displacement of gurban leads not a loss of function of the custom, but to the transformation of the cultural heritage of the migrants in accordance with the new environment ${ }^{29}$. The joint celebration of the feasts for the Rudari has an important role and maintains the kin affiliations, they gather to celebrate together no matter of the big distances between the places, where the relatives live. Informants from Rudari group now are living in Spain. In occasion of the christening of a one-year-old child the family organizes big celebration in restaurant in Burgos with 200 guests. The relatives from Bulgaria, other parts of Spain and Italy are invited too. The ceremony was conducted by an Orthodox priest, also immigrant in Spain and of Bulgarian ethnic origin.

Gurbet influences the self-esteem of the people and their living standards upon their return to Bulgaria. Besides being better - off than their neighbours and acquaintances, which they never fail to demonstrate, those who have returned from gurbet start feeling Europeans, because they have left their native neighbourhood, have been to the west and have tackled the challenges abroad. "European=Spanish" is demonstrated by various means. Informants from Karnobat (Southeastern Bulgaria) gave a party to their son's prom in May 2007 in a restaurant. The father organized the celebration in the way "the Spanish do it". The only difference is that the school graduate is not given presents. Instead every one of the guests leaves an envelope with some cash inside. 
Upon their return to Bulgaria many of the men start up their own business - in construction, mushroom exports, cars imports and exports, etc. They become the new "businessmen" of the neighbourhood.

On important family gatherings such as a wedding or a funeral the migrants do their best to return to Bulgaria to attend. Migrants I met in Murcia told me by all means to go and see their elderly mother in Peshtera, if I happened to go there. I did go to Peshtera, but the woman in question had died. Her sons and daughters-in-law had arrived for the funeral from Murcia. One of the greatest blows to a migrant is the impossibility to attend the funeral of a close person or the wedding of a relative. This fear is common to all emigrants regardless of their religion and ethnicity. The youth in emigration try by all means to marry someone from their native place. The real nice celebrations and occasions are held in Bulgaria. Spain is for work, whereas Bulgaria is the place to live "in the Spanish manner".

Under the terms of cross-border labour mobility (and emigration) the multidimensional structure of the Gypsies' identity gains new dimensions. Identity is not a static category and often has situational character, so that in different social conditions of living various markers of belonging to the community are demonstrated. The Gypsies revise the idea of self and "other" in ethnic context. The distinction between Gypsy and non-Gypsy (Gadže) is preserved. Regional belonging and the native place acquire greater importance than before. The Gypsies manage to sustain some kind of isolation as community within the migration flow (mostly on the level of groups or coming from the same place) during their settling in Spain. The Bulgarian Gypsies preserve their ethnic belonging to a community (Gypsies and their preferred identity as Bulgarians, Turks or Romanians) and differ from the rest of the Gypsies by most diverse specific categories - way of life, mother tongue, religion, culture, occupation. In some situations the Gypsies are able to demonstrate a feeling of solidarity in the labour sphere or to consider the Bulgarians closer than the rest of the Gypsies. This is a process of self-consciousness as part of the Bulgarian nation, although at the level of an ethnic minority ("Bulgarian" Gypsies). This identity is felt more strongly in emigration than at home. On the other hand, unlike everyone else, Evangelists are able to feel other Gypsy groups, such as the Gitanos or the Romanian Gypsies closer due to the fact that they too are believers, and not because they are Gypsies. Life in emigration strengthens the faith in Jesus Christ and becomes a form of adaptation.

When in emigration (or labour mobility) the processes of developing the preferred ethnic identity (and/or the creation of a new identity) among some Gypsy groups have interesting manifestations. Life in a foreign-language environment and the linguistic proximity of the Spanish, Italian and Romanian languages gives the Rudari from Bulgaria ground to feel that they share common origins with the Spanish and Italians. Their stay in both countries enhances the feeling of Rudari identity and proves they have nothing in common with the "Gypsies" and that they belong to a separate Rudari community that has its own history and origins. According to some informants the Rudari, Italians and Spanish bore a physical resemblance (they shared an anthropological closeness).

Bulgaria's EU entry enhanced the feeling of the Gypsies of belonging to the European community. During my field work in Spain all the immigrants said they hoped Bulgaria would join the EU in 2007. According to the informants, the event was of particular 
importance because as EU citizens they would enjoy greater privileges. The migrants and their families discussed Bulgaria's EU entry even over the phone.

\section{Conclusion}

The labour migration of Bulgarian Gypsies to Spain is a process that develops at various paces through the years. The Gypsies and the surrounding population take part common migration flows and are part of a common trend of practising migration labour abroad as a direct consequence of the social and economic crisis after the fall of the socialist regime in the country. The Gypsies together with the rest of the Bulgarian citizens developed similar adaptation strategies abroad. Some of those who leave are temporary migrants, who return to Bulgaria sooner or later, while others turn from labour migrants into emigrants settling permanently in the host country and adjusting to the "Spanish way of life". Gradual interrupting of relations with the country of origin, thus legalization, permanent settling and socialization of migrants in the new societies in Spain, could be expected. Appearance of migrant clusters is one of the main results from the transnational labor migration in addition. The migration shifts lead in the end to a new picture of the Gypsy presence in Spain.

The complex structure of Gypsy identities gains new dimensions in emigration and shows that the processes are often influenced by factors that are external to the community/communities. The boundaries among the individual Gypsy communities are maintained, and so is the distinction between Gypsy and non-Gypsy. The new way of life and the "journey" to Spain give grounds to many Gypsies from Bulgaria to feel "Gypsies in Europe".

\section{NOTES}

1. See Marushiakova (Elena), Popov (Vesselin), Tsiganite $v$ Balgaria [Gypsies in Bulgaria], Sofia : Club'90, 1993 ; Marushiakova (Elena), Popov (Vesselin), «Bulgaria: Ethnic Diversity - a Common Struggle for Equality », in Guy (Will), ed., Between Past and Future. The Roma of Central and Eastern Europe, Hatfield Hertfordshire : University of Hertfordshire Press, 2001.

2. Postanovlenie N-258 na Ministerski Savet ot 17.12. 1958 [Decree No. 258 of the Council of Ministers]. - Tsentralen darzhaven arkhiv, F. 1, op. 28, A.E. 15.

3. See Marushiakova (Elena), Popov (Vesselin), op.cit.

4. See Marushiakova (Elena), «Gypsy/Roma Identities in New European Dimensions : The case of Eastern Europe ", in Marushiakova (Elena), ed., Dynamics of National Identity and Transnational Identities in the Process of European Integration, Cambridge : Cambridge Scholars Publishing, 2008 ; Popov (Vesselin), «The Gypsy/Roma between the Scylla of Marginalization and the Charybdis of Exotisation in New EU Realities », in ibid.

5. See Marouchiakova (Elena), Popov (Vesselin), « De l'Est à l'Ouest. Chronologie et typologie des migrations tsiganes en Europe », Etudes tsiganes. Migrations tsiganes, (27-28), 2006.

6. See Ibáñez Angulo (Monica), «Nation Building within the European Union: Reframing Bulgarian National Identity from Abroad », in Marushiakova (Elena), ed., op.cit. 
7. See Ramírez Goicoechea (Eugenia), Inmigrantes en España. Vidas en experiencias, CIS : Madrid, 1996 ; Hellermann (C.), Stanek (M.), « Nuevas perspectivas en los estudios sobre la inmigración de Europa central y oriental en España y Portugal », Papeles del Este, (11), 2006.

8. Markova (Eugenia), «Legal Status and Migrant Economic Performance. The Case of Bulgarians in Spain and Greece », paper presented at the conference To be a European. Bulgaria and Europe in Europe: Past, Present and Future, London: University College, 5 March 2004 ; Rangelova (Rossitsa), Vladimirova (Katia), "Migration from Central and Eastern Europe: the Case of Bulgaria », South-East Europe Review, (3), 2004; Markova (Eugenia), Reilly (Barry), «Bulgarian Migrant Remittances and Legal Status : Some Micro-level Evidence from Madrid», South-Eastern Europe Journal of Economics, (1), 2007.

9. See Ibáñez Angulo (Monica), art.cit.

10. Guentcheva (Rossitza), Kabakchieva (Petya), Kolarski (Plamen), Migration Trends in Selected EU Applicant Countries. Vol. 1 Bulgaria. The Social Impact of Seasonal Migration, Viena : IOM., 2004, p. 82.

11. Marushiakova (Elena), Popov (Vesselin), « Bulgarian Gypsies in Exile. Migration and Gypsy Traditions », Migration. European Journal of International Migration and Ethnic Relation, 2006.

12. Ibid.

13. INE, Revisión del Padrón municipal 2007. Población extranjera por sexo, comunidades y provincias y nacionalidad, 2007.

14. Ringold (Dena), Roma and the Transition in Central and Eastern Europe: Trends and Challenges, Washington, DC: The World Bank, 2000; Ringold (Dena), Orenstein (Mitchell), Wilkens (Erika), Roma in an Expanding Europe - Breaking the Poverty Cycle, Washington, DC : International Bank for Reconstruction and Development, 2003.

15. Marushiakova (Elena), Popov (Vesselin), Decheva (Mirella), « The Gypsies in Bulgaria and their Migrations », in Guy (Will), Uherek Zdenek), Weinerova (Renata), eds., Roma Migration in Europe: Case Studies, Münster : Lit, 2004 ; Marushiakova (Elena), Popov (Vesselin), « Bulgarian Gypsies in Exile. Migration and Gypsy Traditions » (art.cit.).

16. See Karamihova (Margarita), ed., Da zhiveesh tam, da sanuvash tuk. Emigratsionni protsesi $v$ nachaloto na XXI vek [Living there, dreaming here. Emigrational attitudes in the beginning of 21 century], Sofia : IMIR, 2003.

17. Ibid.

18. Rangelova (Rossitsa), Vladimirova (Katia), art.cit.; Markova (Eugenia), Reilly (Barry), art.cit.

19. Ministerio de trabajo y asuntos socialEs [Ministry of Labor and Social Affairs] 2005 - http:// www.mtas.es/balance/pagina8.htm

20. Gamella (Juan), «L'immigration ignorée : les Roms roumains en Espagne », Etudes tsiganes. Migrations tsiganes, (27-28), 2006.

21. SlavkovA (MAgdalena), Tsiganite evangelisti v Balgaria [Evangelical Gypsies in Bulgaria], Sofia : Paradigma, 2007.

22. Ruiz Vieytez (Eduardo Javier), Ruiz Lopez (Blanca), Las políticas de inmigración. La legitimación de la exclusión, Bilbao : Universidad de Deusto, 2001 ; Ibáñez Angulo (Monica), art.cit. 23. Gamella (Juan), art.cit.

24. Slavkova (Magdalena), "Contemporary labor migrations of Gypsies from Bulgaria to Spain ", in Marushiakova (Elena), ed., Dynamics of National Identity and Transnational Identities in the Process of European Integration, Cambridge : Cambridge Scholars Publishing, 2008.

25. Marushiakova (Elena), Popov (Vesselin), Decheva (Mirella), art.cit.; Marushiakova (Elena), Popov (Vesselin), «Bulgarian Gypsies in Exile. Migration and Gypsy Traditions » (art.cit.). 
26. Peycheva (Lozanka), Dimov (Ventsislav), «Migratsii i gurbeti ot Balgaria : muzikalni orbiti » [Migrations and migrants work coming from Bulgaria : music orbits], in Karamihova (Margarita), ed., Gradivo za ethnologiya na migratsiite, Sofia : EIM-BAN, 2006.

27. Ibid.

28. Markova (Eugenia), Reilly (Barry), art.cit. ; Karamihova (Margarita), ed., op.cit.

29. Sorescu Marinković (Annemarie), "The gurban displaced: Bayash guest workers in Paris ", in Sikimić (Biljana), Hristov (Petko), eds., Kurban in the Balkans, Belgrade : Serbian Academy of Sciences and Arts / Institute for Balkan Studies, p. 148.

\section{ABSTRACTS}

The changes following the collapse of the Socialist regime in Bulgaria - 19 years of social and economic crises - have resulted in waves of migration toward Western Europe. Spain has become one of the most popular destinations for Bulgarians working abroad. In this article about labour migration from Bulgaria to Spain in the years 1990-2008, I write about the new concepts of "Gypsyness" generated by this new transnational labor mobility. My key objective is to demonstrate how the choices of employment made by migrating Gypsies are adaptation strategies. The Gypsies and the surrounding non-Gypsy Bulgarian population all take part in common migration flows - part of the tendency to work abroad to cope with the social and economic changes resulting from the fall of the socialist regime in the country. Some migrate temporarily while others become permanent immigrants, settling in the host country and adjusting to the "Spanish way of life". These migration shifts have lead to the emergence of new social representations of the Gypsies in Spain (and in Europe).

\section{INDEX}

Geographical index: Bulgarie, Espagne

Mots-clés: Roms, Tziganes, Migrations

\section{AUTHOR}

\section{MAGDALENA SLAVKOVA}

Dr. Magdalena Slavkova is an ethnologist in the Department of Balkan Ethnology at the Ethnographical Institute and Museum, Bulgarian Academy of Sciences, Sofia. Her recent publications include : "Contemporary labor migrations of Gypsies from Bulgaria to Spain », in : Marushiakova, Elena (ed.), Dynamics of National Identity and Transnational Identities in the Process of European Integration, Cambridge : Cambridge Scholars Publishing, 2008, p.189-213; « Săvremenni trudovi migracii na bălgarski cigani kăm Ispania i tiahnoto otraženie vărhu identičnostta im » [Les migrations du travail temporaires des Roms bulgares vers l'Espagne et leurs répercussions sur leur identité], in : Decheva, Mirella (ed.), Dinamika na nacionalnata identičnost $i$ transnacionalnite identičnosti $v$ procesa na evropeiska integracija [Dynamique de l'identité nationale et identités transnationales dans le processus d'intégration européenne], Sofia : Paradigma, 2008, p.289-318; 
Ciganite evangelisti v Bălgarija [Les Roms évangélistes en Bulgarie], Sofia : Paradigma, 2007. mmagdalenaslavkova@yahoo.com 